Saudi Journal of Business and Management Studies Abbreviated Key Title: Saudi J Bus Manag Stud ISSN 2415-6663 (Print) |ISSN 2415-6671 (Online) Scholars Middle East Publishers, Dubai, United Arab Emirates Journal homepage: https://saudijournals.com/sibms

Original Research Article

\title{
The Preference of the Vocational High School Student for Higher Education Online Learning
}

\author{
Yuli Harwani* \\ Lecturer the Department of Management, Universitas Mercu Buana (UMB), Jakarta, Indonesia
}

DOI: $10.36348 /$ sjbms.2020.v05i02.004 $\quad$ | Received: 09.02.2020 | Accepted: 17.02 .2020 | Published: 20.02 .2020

*Corresponding author: Dr. Yuli Harwani

\section{Abstract}

The research for student preferences to study in college or studying while working is scarce. There is a difference between full-time mode and the online learning mode preferences. Since the research on this characteristic is scarce, we are conducting a sample for 203 vocational high school students from 20 schools. The findings show that vocational high school student prefers online learning, working, and studying compare to being full-time student. These findings show that Higher Education should deliver good attributes that could support their needs to learn and also to work. They also want a gradual method of payment, competitive price for tuition, since they are preparing to pay the tuition with their own money, moreover the prefer online learning.

Keywords: Vocational Student, Higher Education, Choice Preference.

Copyright @ 2020: This is an open-access article distributed under the terms of the Creative Commons Attribution license which permits unrestricted use, distribution, and reproduction in any medium for non-commercial use (NonCommercial, or CC-BY-NC) provided the original author and source are credited.

\section{INTRODUCTION}

The student has a different preference for their career, whether they are going to work or going to take a regular class as a full-time student. Since there are a variety of needs related to their background profile, Higher Education needs to find out the needs of the consumer. Therefore Higher Education could deliver relevant products for the targeted consumers.

If Higher Education delivers a relevant product for the student, then the student will have a better off, and the Higher Education will get recognition in terms of the credibility of delivering a relevant benefit to the consumer. There are Higher Education that is delivering a world-class reputation to the consumer; there are also Higher Education that delivers a standard learning process that could support the student, empowering and also provide an opportunity for the student to work in the office. The research in term of observing the needs of the consumer that prefer to work in the office is still scarce. Therefore this research is conducted to fill this gap.
Some of the students have the privilege to become a full-time regular student. Nevertheless, some students have to find an additional income to support the tuition fee. This kind of student would prefer to work and also studying because it will open the opportunity to earn some money and also could improve the background of education. After they are graduated, they will have a better career. By this path of career, the student is not going to sacrifice too many opportunities, they could earn income and also improve education.

Every student also wants to have an excellent Higher Education that could improve their career. Therefore choices of Higher Education becomes more specific because it should support the background profile of the consumers and also improve the competitiveness of the human resources in the labor market.

Since the needs and wants of the consumer are evolving, it is necessary to analyze consumer behavior, preferences, and the target consumer. Some students look for a future career that meets the interest and also the talent they have. Some students look for significant 
revenue and a good salary; the choices influenced by the demand of the parents.

Nevertheless, all of these factors influence student preference to choose Higher Education. Therefore the Higher Education needs to look at and observing which are the dominant factors that will influence the choices and which ones that are less dominant that only will affect interest but not going to make a different decision for the student.

\section{THEORETICAL REVIEW}

Vocational education is playing an important role to create labor that is needed by the company to develop the economy of the nation $[1,2]$. Since in the senior high school, the student trained to have an attribute demanded by the industries. The attribute, namely knowledge, skills, abilities, and personality are nurture in vocational education. The system of vocational education proven to be better to improve the capacity of the human resources compare with the higher indication since higher education mostly focuses only on academics.

Vocational education plays an essential role in developing the quality of the labor market, the improvement of the necessary skills, literacy, and numeracy [3]. Some research shows that vocational education contributes less compared the academic education, nevertheless vocational education could also perform better in the time spend for paid employment. Some findings show that vocational education contributes to improving the capacity development of the student.

Best practice in Germany shows that the transition of the young people from school to the labor market supported by the role of vocational education [4]. There is the relevance between vocational education and also the capacity of the human resources needed by the company.

Moreover, since vocational education will have more time to exercise the attributes needed by the Industry, therefore They will prefer more experience in doing things compare with reading and learning academic aspects. Nevertheless, continuing education is going to shape the future of that a career, the choices of higher education they are going to choose for the further learning process.

Since they will prefer to experience working compare with only learning the theory from the textual books in the higher education, therefore the vocational student will need a relevant service that could support the needs and the wants of the students to develop their academic process. Some research proposes that computer-assisted education programs will help the student in vocational learning to improve their human resources capability [5].
There are pros and cons related to computerassisted education programs. Nevertheless, the computer feature provides a mode to improve their capacity to learn in flexible time. Since they have to work daily, they might also have a shift in working hours. Therefore a flexible time to learn is the requirement needed by the vocational student to continuing the educational process and further contribute to the career process [6].

The vocational student also has a different characteristic compared with the academic student since most of them are prefer to have a vocational education and pursuing to work after graduating from the vocational high school compare with the students that are going to pursue learning in higher education. Some of the reasons the student choose vocational education are to be able to work and earn money. This profile shows that they might have a limited amount of revenue for education. Therefore they will need financial support, and also they might prefer to have a direct career preference after graduated from senior high school vocational education. These are the characteristics of the student in vocational education, that should be supported by the government to improve the quality of their academic education.

This research explores the background profile and also the preferences of the vocational student in West Jakarta to pursue higher education. What is their preference between the face-to-face learning process compare with the online learning process, since the online will provide a flexible time compare with the full-time face to the face learning process? The sample is the student that is learning in the vocational high school in West Jakarta.

\section{RESEARCH METHODS}

The research is descriptive research targeting 20 vocational high schools in the West Jakarta. Each vocational school sample consists of 10 students from the third year. The researchers visit the vocational school after permission granted from the head of the vocational school.

A questionnaire previously delivered to the respondent for a school preference [7] modified to meet the vocational education student preference toward higher education. The researcher also developed a guide as an essential reference for survey.

The survey conducted in 2019, two weeks after the student enrolled in the new academic year. Since it is the only flexible time for the students to be able to accept the visit from the external stakeholders, the survey conducted by pursuing the student to a room provided by the school, and then all the respondent will be delivered the information related to the survey, and then the survey conducted. Furthermore, after the survey finish, the result will be measured in the 
percentage number and the descriptive analysis conducted.

\section{RESEARCH RESULTS}

The survey conducted to find out students' interest in Higher Education, as well as recognizing the level of public awareness of XX Higher Education as one of the choice after they graduated from vocational high school. The area surveyed is West Jakarta. The total target of the vocational high school surveyed is 20 schools, each school contribute ten students each school.

There are questions related to reasons to chose continuing education at Vocational High School. The result for five most answers is first to work right away, second to master a particular field or vocational, third to increase knowledge, fourth personal desires, and fifth to obey the parents (Table-1).

\section{Table-1: Student Preference for Continuing Education}

\begin{tabular}{|l|l|l|}
\hline Answer Choices & $\%$ & $\mathrm{n}$ \\
\hline To Work Immediately & $80.30 \%$ & 163 \\
\hline Field Study / Vocational & $28.08 \%$ & 57 \\
\hline To Increase Knowledge & $23.15 \%$ & 47 \\
\hline Personal Desires & $16.75 \%$ & 34 \\
\hline Parent Influence & $16.26 \%$ & 33 \\
\hline Practicing Skills & $14.29 \%$ & 29 \\
\hline Training Skills & $11.33 \%$ & 23 \\
\hline Continuing to a higher level & $10.84 \%$ & 22 \\
\hline
\end{tabular}

Questions related to 5 Private Universities the respondent recognize in Jabodetabek, the top 5 answers are $\mathrm{T}$ University, $\mathrm{M}$ University, Ta University, $\mathrm{B}$ University, and E University. Questions related to the profession the student prefer after graduation result top 5 answers which are entrepreneur, manager, accountant, private employee, and secretary (Table-2).

Table-2: Preferred Profession

\begin{tabular}{|l|l|l|}
\hline Answer Choices & $\%$ & $\mathrm{n}$ \\
\hline Entrepreneur & $33.00 \%$ & 67 \\
\hline Manager & $33.00 \%$ & 67 \\
\hline Accountant & $23.15 \%$ & 47 \\
\hline Private employees & $18.23 \%$ & 37 \\
\hline Secretary & $18.23 \%$ & 37 \\
\hline Teacher & $12.32 \%$ & 25 \\
\hline Doctor & $6.40 \%$ & 13 \\
\hline Civil servants & $5.91 \%$ & 12 \\
\hline
\end{tabular}

The result relates to the vocational high school profile that has four major, which are accounting, marketing, office administration, and computers and network engineering (Table-3).

Table-3: Profile Respondent High School

\begin{tabular}{|l|l|l|}
\hline Answer Choices & $\%$ & $\mathrm{n}$ \\
\hline Accounting & $64.32 \%$ & 128 \\
\hline Marketing & $24.62 \%$ & 49 \\
\hline Office administration & $6.03 \%$ & 12 \\
\hline Computer and Network Engineering & $5.03 \%$ & 10 \\
\hline
\end{tabular}

For the next question, relate to what the student wants to be, they said they want to be excellent graduates. Furthermore, they want to get a job. It means the respondents want to become a qualified graduate and find jobs easily (Table-4).

Table-4: Student Objective

\begin{tabular}{|l|l|l|l|l|}
\hline I want to be & \% & n & \multicolumn{1}{l|}{$\%$} & n \\
\hline & \multicolumn{2}{|l|}{ Strongly Agree } & \multicolumn{2}{|l|}{ Agree } \\
\hline Graduates who have good quality. & $80.30 \%$ & 163 & $18.72 \%$ & 38 \\
\hline Graduates who find jobs easily. & $73.40 \%$ & 149 & $26.11 \%$ & 53 \\
\hline
\end{tabular}

For the next few questions, respondent agrees that the cost of high education illustrates the high quality of education, the second point is whether the cost of high education guarantees the process to become a qualified graduate, most of the respondent agrees. The third point, whether the payment method of tuition fees gradually becomes the primary determinant in choosing Higher Education. Most answers agreed. The next point is whether the cost of education becomes the deciding factor in choosing the Higher Education; most of the respondents agreed (Table-5).

Table-5: Student Cost Preference

\begin{tabular}{|l|l|l|l|l|}
\hline Give your views on this statement: & $\%$ & $\mathbf{n}$ & $\mathbf{\%}$ & $\mathbf{n}$ \\
\hline & \multicolumn{1}{|l|}{ Strongly Agree } & \multicolumn{2}{|l|}{ Agree } \\
\hline High education costs illustrate the high quality of education. & $13.79 \%$ & 28 & $39.90 \%$ & 81 \\
\hline High tuition fees guarantee the process of becoming a quality graduate. & $6.90 \%$ & 14 & $37.93 \%$ & 77 \\
\hline $\begin{array}{l}\text { The method of payment of tuition fees has gradually become the primary } \\
\text { determinant in selecting Higher Education. }\end{array}$ & $17.73 \%$ & 36 & $41.87 \%$ & 85 \\
\hline $\begin{array}{l}\text { The amount of tuition fees is the primary determinant in choosing Higher } \\
\text { Education. }\end{array}$ & $10.84 \%$ & 22 & $44.83 \%$ & 91 \\
\hline $\begin{array}{l}\text { The availability of scholarships at Higher Education becomes the primary } \\
\text { consideration in choosing where to study. }\end{array}$ & $37.44 \%$ & 76 & $46.31 \%$ & 94 \\
\hline The name of the Higher Education is a guarantee of ease of getting a job. & $21.78 \%$ & 44 & $42.08 \%$ & 85 \\
\hline
\end{tabular}


Furthermore, the respondent agrees that the availability of scholarships in Higher Education is the deciding factor to choose Higher Education. The last point is whether the name of the college is guaranteed to get the job; most of the respondent agrees.

The research findings show that higher education costs describe the quality of education. The cost of education is a guarantee for a good quality graduate, and gradual method of payment, the amount of tuition fees is the primary determinant for the availability of the scholarships, it is the primary determinant to choose Higher Education.
The student also asked whether they prefer Higher Education that have an excellent social environment. Most of the respondent agrees. The location of the Higher Education, which is not far from their home, is preferable, furthermore they prefer the location of Higher Education that is easily reached by public transportation. It concluded that the respondents choose Higher Education with a pleasant social environment, the location near their home, and supported by easy public transportation (Table-6).

Table-6: Student Preference for Higher Education Environment

\begin{tabular}{|l|l|l|l|l|}
\hline Give your views for this statement: & \% & $\mathbf{n}$ & $\mathbf{\%}$ & $\mathbf{n}$ \\
\hline & Strongly Agree & \multicolumn{1}{|l|}{ Agree } \\
\hline Higher Education has an excellent social environment. & $56.16 \%$ & 114 & $37.93 \%$ & 77 \\
\hline The location of Higher Education is not far from the residence. & $26.11 \%$ & 53 & $55.67 \%$ & 113 \\
\hline The location of Higher Education is easily accessible by public transportation. & $53.20 \%$ & 108 & $40.89 \%$ & 83 \\
\hline
\end{tabular}

Furthermore, the respondent stated that parents have a significant influence on the process of determining colleges and study programs. Nevertheless, the respondent did not agree that friends have a significant role in the process of choosing a college. Furthermore, the information from the college is more trusted compare with the information from friends. It concluded that the respondent prefers to choose Higher Education and study programs, parents play an essential role to choose Higher Education, and the students trust the information directly provided by the college, rather than information from peers (Table-7).

Table-7: Student Influencer

\begin{tabular}{|c|c|c|c|c|}
\hline Give your views for this statement: & $\%$ & n & $\%$ & n \\
\hline & \multicolumn{2}{|c|}{ Strongly Agree } & \multicolumn{2}{|l|}{ Agree } \\
\hline $\begin{array}{l}\text { Parents have a significant influence on the process of determining the chosen } \\
\text { Higher Education. }\end{array}$ & $27.59 \%$ & 56 & $33.50 \%$ & 68 \\
\hline Parents have a significant influence in choosing study programs. & $9.85 \%$ & 20 & $30.54 \%$ & 62 \\
\hline $\begin{array}{l}\text { The nuclear family, besides parents, plays a significant role in the process of } \\
\text { selecting Higher Education. }\end{array}$ & $7.88 \%$ & 16 & $34.48 \%$ & 70 \\
\hline Friends have a significant role in the process of choosing a Higher Education. & $1.98 \%$ & 4 & $26.73 \%$ & 54 \\
\hline $\begin{array}{l}\text { Information from friends can be more trusted than information that comes from } \\
\text { Higher Education. }\end{array}$ & $5.42 \%$ & 11 & $6.90 \%$ & 14 \\
\hline $\begin{array}{l}\text { Information from BK teachers and schools is more reliable than information } \\
\text { from Higher Education. }\end{array}$ & $4.43 \%$ & 9 & $23.15 \%$ & 47 \\
\hline $\begin{array}{l}\text { Information from BK teachers has a significant influence in choosing Higher } \\
\text { Education. }\end{array}$ & $8.87 \%$ & 18 & $25.62 \%$ & 52 \\
\hline $\begin{array}{l}\text { Information from BK teachers (Consulting teacher) and schools about Higher } \\
\text { Education is accurate. }\end{array}$ & $7.88 \%$ & 16 & $33.50 \%$ & 68 \\
\hline
\end{tabular}

Furthermore, the ability of talent and interest is the primary consideration to choose a study program. The availability of study programs relevant to the results of aptitude tests and the interest is the primary consideration to choose a higher institution. Location and social environment in the higher institution are essential considerations to choose higher institutions.
Nevertheless, the limited capacity of higher institutions is a consideration to choose. So, the ability of talent and interest, the availability of study programs, the location of a pleasant social environment, and the capacity are the primary consideration to choose Higher Education (Table-8). 
Yuli Harwani; Saudi J Bus Manag Stud, Feb., 2020; 5(2): 132-137

Table-8: Student Preference to Study

\begin{tabular}{|l|l|l|l|l|}
\hline Give your views for this statement: & \% & $\mathbf{n}$ & $\%$ & $\mathbf{n}$ \\
\hline & \multicolumn{2}{|l|}{ Strongly Agree } & \multicolumn{1}{|l|}{ Agree } \\
\hline My talents \& interests are the primary consideration in choosing study programs. & $48.28 \%$ & 98 & $48.28 \%$ & 98 \\
\hline $\begin{array}{l}\text { The availability of study programs by the results of my aptitude \& interest tests } \\
\text { is the primary considerations in choosing Higher Education. }\end{array}$ & $35.82 \%$ & 72 & $54.23 \%$ & 109 \\
\hline $\begin{array}{l}\text { The location and social environment in Higher Education become essential } \\
\text { considerations in choosing Higher Education. }\end{array}$ & $25.12 \%$ & 51 & $55.17 \%$ & 112 \\
\hline $\begin{array}{l}\text { The limited capacity of Higher Education seats is a consideration in determining } \\
\text { Higher Education. }\end{array}$ & $9.90 \%$ & 20 & $45.05 \%$ & 91 \\
\hline
\end{tabular}

The respondent asked whether the Higher Education that excellent in quality of teaching become the primary choice; most of the respondents agree. Furthermore, low-cost universities are the primary choice; universities with access to a location that is easy to reach is the primary consideration. Respondent stated that Higher Education or study programs with A Accreditation are the primary choice. Higher Education that has good buildings and facilities are the best choice, Higher Education with many student programs are the primary considerations, and Higher Education that has international cooperation will be the preferred choice. The study program relevant to the results of interest and aptitude tests is the first choice. Finally, it can be concluded that Higher Education that has superior quality in teaching, low cost, easy to reach, have A Accreditation, available supporting facilities, have many student programs, established international cooperation relationships are the main considerations to choose for the Higher Education (Table-9).

Table-9: Student Preference for Higher Education

\begin{tabular}{|l|l|l|l|l|}
\hline Give your views for this statement: & \% & $\mathbf{n}$ & $\%$ & $\mathbf{\%}$ \\
\hline & \multicolumn{2}{|l|}{ Strongly Agree } & \multicolumn{1}{|l|}{ Agree } \\
\hline Higher Education that excels in teaching quality becomes the primary choice. & $47.29 \%$ & 96 & $43.35 \%$ & 88 \\
\hline Higher Education with low cost becomes the primary choice. & $38.42 \%$ & 78 & $45.81 \%$ & 93 \\
\hline $\begin{array}{l}\text { Higher Education with access to easily accessible locations is a significant } \\
\text { consideration. }\end{array}$ & $42.36 \%$ & 86 & $45.32 \%$ & 92 \\
\hline $\begin{array}{l}\text { Higher Education or study programs with accreditation A become the primary } \\
\text { choice. }\end{array}$ & $50.74 \%$ & 103 & $39.41 \%$ & 80 \\
\hline Higher Education that has proper buildings and facilities are the best choice. & $38.42 \%$ & 78 & $41.87 \%$ & 85 \\
\hline $\begin{array}{l}\text { Higher Education, with many student programs, is the primary considerations to } \\
\text { be chosen. }\end{array}$ & $29.70 \%$ & 60 & $55.94 \%$ & 11 \\
\hline Higher Education that has international cooperation will be the first choice. & $40.39 \%$ & 82 & $46.31 \%$ & 94 \\
\hline $\begin{array}{l}\text { Study programs that match the results of aptitude \& interest tests will be the } \\
\text { first choice. }\end{array}$ & $41.09 \%$ & 83 & $46.04 \%$ & 93 \\
\hline
\end{tabular}

There are also questions relating to the mode of learning and working. Most of the respondents are considering studying online at Higher Education. There are 156 respondents said Yes, and only 47 respondents said No. Furthermore, the respondent preferred working and studying in the college; they did not prefer as a fulltime student. 196 respondents consider going to college while working (Table-10).

Table-10: Student Willingness to Study Online

\begin{tabular}{|l|l|l|l|l|l|}
\hline Give your views for this statement: & $\mathbf{\%}$ & $\mathbf{n}$ & $\mathbf{\%}$ & $\mathbf{n}$ \\
\hline \multicolumn{2}{|l|}{} & Strongly Agree & \multicolumn{2}{|l|}{ Agree } \\
\hline Are you considering studying online at this (XX) Higher Education? & $23.65 \%$ & 48 & $42.36 \%$ & 86 \\
\hline
\end{tabular}

The question, if you get two choices of face-toface lectures or work while studying online, what choice do you take? Most of the answer said, working while studying online with 105 respondents, and with face-to-face 98 respondents. It interpreted that more people choose to work and to study online compared to face to face (Table $11 \& 12$ ).

Table-11: Student Preference to Study and Work

\begin{tabular}{|l|l|l|}
\hline Do you want to go to college while working? & & \\
\hline & $\%$ & $\mathrm{n}$ \\
\hline Yes & $96.55 \%$ & 196 \\
\hline No & $3.45 \%$ & 7 \\
\hline
\end{tabular}


Table-12: Student Preference to Study

\begin{tabular}{|l|l|l|}
\hline $\begin{array}{l}\text { If you get two choices for the face-to-face learning process compare } \\
\text { to work while studying online, what choice will you make? }\end{array}$ & \\
\hline & $\%$ & $\mathrm{n}$ \\
\hline Face to face & $48.28 \%$ & 98 \\
\hline Work - Online lectures & $51.72 \%$ & 105 \\
\hline
\end{tabular}

Finally, the question related to preferred the study program is accounting, management, office administration, banking, and fifth psychology. The interesting about this survey is that the most answers from the profession or job you want after graduating are to become an entrepreneur.

\section{CONCLUSION}

The research conducted for the vocational student shows that the vocational high school student prefers to work and studying in Higher Education. To meet the needs and wants of the student from the vocational school, the Higher Education should make a learning process services that could meet their needs such as an online learning class that minimize the face to face interaction, an efficient payment, a gradual method of payment.

\section{REFERENCES}

1. Rajadurai, J., Sapuan, N. M., Daud, S., \& Abidin, N. (2018). The Marketability of Technical Graduates from Higher Educational Institutions (HEIs) Offering Technical and Vocational Education and Training (TVET): A Case from Malaysia. The Asia-Pacific Education Researcher, 27(2), 137-144.
2. Rönnlund, M., Rosvall, P. Å., Johansson, M., Samhällsvetenskapliga, F., Institutionen För Tillämpad, U., Umeå, U., \& Barn-Och Ungdomspedagogik, S. O. V. (2018). Vocational or academic track? Study and career plans among Swedish students living in rural areas. Journal of Youth Studies, 21(3), 360-375.

3. Brunello, G., \& Rocco, L. (2017). The effects of vocational education on adult skills, employment and wages: What can we learn from PIAAC? SERIEs, 8(4), 315-343.

4. Ertl, H. (2020). Dual study programmes in Germany: blurring the boundaries between higher education and vocational training? Oxford Review of Education, 46(1), 79-95.

5. Raji, B., \& Raji, B. (2019). Significance and challenges of computer assisted education programs in the UAE: A case study of higher learning and vocational education. Education and Information Technologies, 24(1), 153-164.

6. Shimoni, A., Gutentag, T., \& Gati, I. (2019). Assessing career preference cohesiveness. Journal of Vocational Behavior, 112, 51-63.

7. Sihite, J. (2019). The Student Preference to Choose Higher Education: A Case Study in West Jakarta 2019. European Journal of Business and Mangement, 11(34), 59-64. 